\title{
Parenthood and the Wayana People
}

\author{
Maurizio Alì, Rodica Ailincai \\ University of French Polynesia (Research Laboratory on Traditional and Contemporary Societies in \\ Oceania-EASTCO), Faa'a, France \\ Email: r.ailincai@gmail.com
}

Received 31 May 2016; accepted 10 July 2016; published 13 July 2016

Copyright (C) 2016 by authors and Scientific Research Publishing Inc.

This work is licensed under the Creative Commons Attribution International License (CC BY).

http://creativecommons.org/licenses/by/4.0/

(c) (i) Open Access

\begin{abstract}
This paper presents the first results obtained from an exploratory study which is conducted within the Amerindian Wayana communities who inhabit the Amazon sector of the High Maroni area, in French Guiana. Based on an ecological and interactionist approach and employing comprehensive methods to analyze observed facts (to bypass the nostalgic attitude fostering the paradigmatic anthropological dichotomy "tradition vs; modernity"), this study describes educational family practices among Wayana and analyses parents' expectations vis-à-vis their children in the framework of the postcolonial dynamic, with the aim to understand the influence of the national public policies to diffuse certain domestic praxis. The ethnographic corpus is gathered during a long fieldwork and it is accompanied by seventeen semi-open interviews. The interpretative approach attempts to link the observed behaviours observed to contextual and cultural variables. Following the analysis of the data, the authors propose 1) a diagram of the structure of Wayana family kinship Microsystems (with a description and a diagram of the Wayana matrilineality scheme); 2) a description of roles and educational functions within their communities and, finally, 3) an overview of parental expectations interpreted taking into account the influences of contemporary inter-systemic interactions (and above all the dynamics generated by the recent introduction of compulsory schooling into the area).
\end{abstract}

\section{Keywords}

Cultural Minority, Education, French Guiana, Parenting, Social Success, Wayana

\section{Aim of the Study and Theoretical Framework}

Today, around a thousand Wayana live in French Guiana, cohabitating with fifty Apalaï. These groups, who have been present in Guiana for at least two centuries, were semi-nomadic in the past (ancestors of the Wayana who were also known as "Roucouyennes"1 and the Apalaï, "Oupouloui”) (Hurault, 1968, 1972). At the present

${ }^{1}$ The name "roucouyennes" comes from the habit of painting the whole body in red with extracts from the roucou plant (Bixa orellana), which leaves the skin a bright red colour. 
time, all of the Guiana Wayana and Apalaï have abandoned the nomadic lifestyle to settle in the indigenous villages of the High Maroni region: Elahé, Cayodé, Twenké, Taluwen, Antecume pata and Pidima on the Guyanese side, and Anapaiké, Alawa and Koumakapan on the Surinamese side.

In our research, we sought to understand parenting practices within indigenous Wayana groups through observations and interviews with the aim to show the peculiarity of this "peripheral" education style, the logic of parenting and the strategies adopted by this autochthonous community to transmit the local knowledge and the cultural data linked with its natural environment. Our study drew upon a symbolic interactionist approach (Mead, 1928, 1930; Blumer, 1969) and an ecological approach (Bronfenbrenner, 1979, 1986).

Firstly, we attempted to give meaning to the actions that the individual has with others by using a comprehensive interpretation of the interactive interpersonal situations observed. We used the ideas suggested by Blumer (1969) for whom the meaning of the exchanges was based (pauses) on the gestural and language symbols shared by the individuals whom we observed. As such, the observations we present here will be based on the meanings and values that parents give to their respective behaviour. The ecological approach also rallies an ethno-methodological vision (Garfinkel, 1967) by the researcher who has to understand the meaning-construction process with the other actors in their everyday lives and interactions i.e. the "common sense" put into practice.

Our second theoretical and methodological orientation is the ecological approach which has animated many scholars giving rise to countless explanatory and comprehensive models (Berry, 1971, 1994; Bronfenbrenner, 1979, 1995; Bronfenbrenner \& Morris, 1998; Levine, 1967; Ogbu 1985, 1990; Super \& Harkness, 1986, 1997; Valsiner, 1987). We shall now briefly present those who have inspired us in this research.

According to the ecological and cultural theoretical framework developed by Berry (1971, 1976, 1987, 1995), the individual and his/her environment mutually influence each other. This approach holds that culture is the functional adaptation of individual behaviour to the ecological and socio-political context, whilst individual and collective diversity is the result of a series of reciprocal adaptations. According to Berry, when considered at a macro-environmental level, this model is a general paradigm through which comparative analysis could provide data on both cultural diversity and the influence of culture on behaviour (through transmission and acculturation).

Bronfenbrenner (1979) proposed a developmental model in which a set of interlinked and interlocked media (microsystems) acted on the cognitive development of the child. The microsystem (the individual's close environment) is included in the mesosystem (the whole set of microsystems), which, in turn, is included in the exosystem (the system of external forces having a strong impact on the microsystem, e.g. policies, regulations, finance, etc.). All of these are held in a macrosystem (systems of remote forces with a long term influence, e.g. values and culture). Bronfenbrenner's theory of ecological systems enables us to understand the global context in which a child develops. According to him, all of the above-mentioned systems operate in an interactive dynamic within which the child constitutes the most internal structure. Bronfenbrenner's macro approach was completed by a bio-ecological systems model (Bronfenbrenner \& Ceci 1994; Bronfenbrenner, 1995; Bronfenbrenner \& Morris 1998, Bronfenbrenner, 2005), which focused more on the role of microsystem and the processes of child development.

\section{Methodology}

The theoretical framework used in our work called for a qualitative research method. Thus, in our research we used ethnographic observation which was then coupled with open-ended interviews. We considered that immersion into the Wayana community was the most efficient way to observe and identify parenting practices within the Wayana community and, more specifically, the parents' conduct.

Two people collected the data. Researcher one carried out punctual observations during several stays of at least one week's duration. "Observer" status was not announced in advance in order not to perturb the natural development of events and practices, thus total immersion was assured by the status of guest within a Wayana family. Afterwards, the researcher asked the families concerned for authorization to write about the events she observed or in which her participation was permitted. This context of our research meant that note-taking was sometimes impossible during observation; nevertheless, the facts relevant to our study were recorded at the earliest opportunity. Although this method is advantageous in terms of the rich and accurate data it provides, it risks refusal on the part of the target community.

The second researcher obtained a contract as a primary school teacher and moved to the village as a long-term resident. His position as a teacher provided him with an ideal situation in which to collect quality data. 
The respective positions held by the observers allowed for two forms of objectification:

- The external position as an outsider (notably for the first observer) necessitated a gradual appropriation of the environment through direct observation (not as a participant); and a comprehensive approach. The difficulty in this posture was to make what is unfamiliar, something familiar.

- The internal position as a participant observer (notably for the second observer), required a different vision of the experienced reality (being oneself in the world he observes). Here it is a question of distancing oneself from the object of the study whilst understanding it at the same time. The difficulty here was to make what has become familiar, something unfamiliar.

Given the comprehensive method used, we found it helpful to combine our points of view with those of the observed parents, through open-ended interviews. The use of these two methods enabled us to complement and compare, for a better understanding of the context, the views of the researcher (which is normally associated with objectivity as they are considered as representations of the natural context in written form), with those of the parents (which is often associated with some subjectivity linked to stated practices).

\section{Population and Place of the Study}

The population of this study is composed of Wayana families who are French (through their nationality at birth) and allophone (through their mother tongue, Wayana) living in French Guiana, on the High Maroni river border with Suriname (see Figure 1).

Our observations were conducted in the villages of Antecume Pata Twenké, Taluen and Cayodé. These isolated villages all have a primary school, although they are located more than $300 \mathrm{~km}$ point-to-point distance away from Cayenne, the capital of the département, in the "Indigenous Country”² (see Table 1).

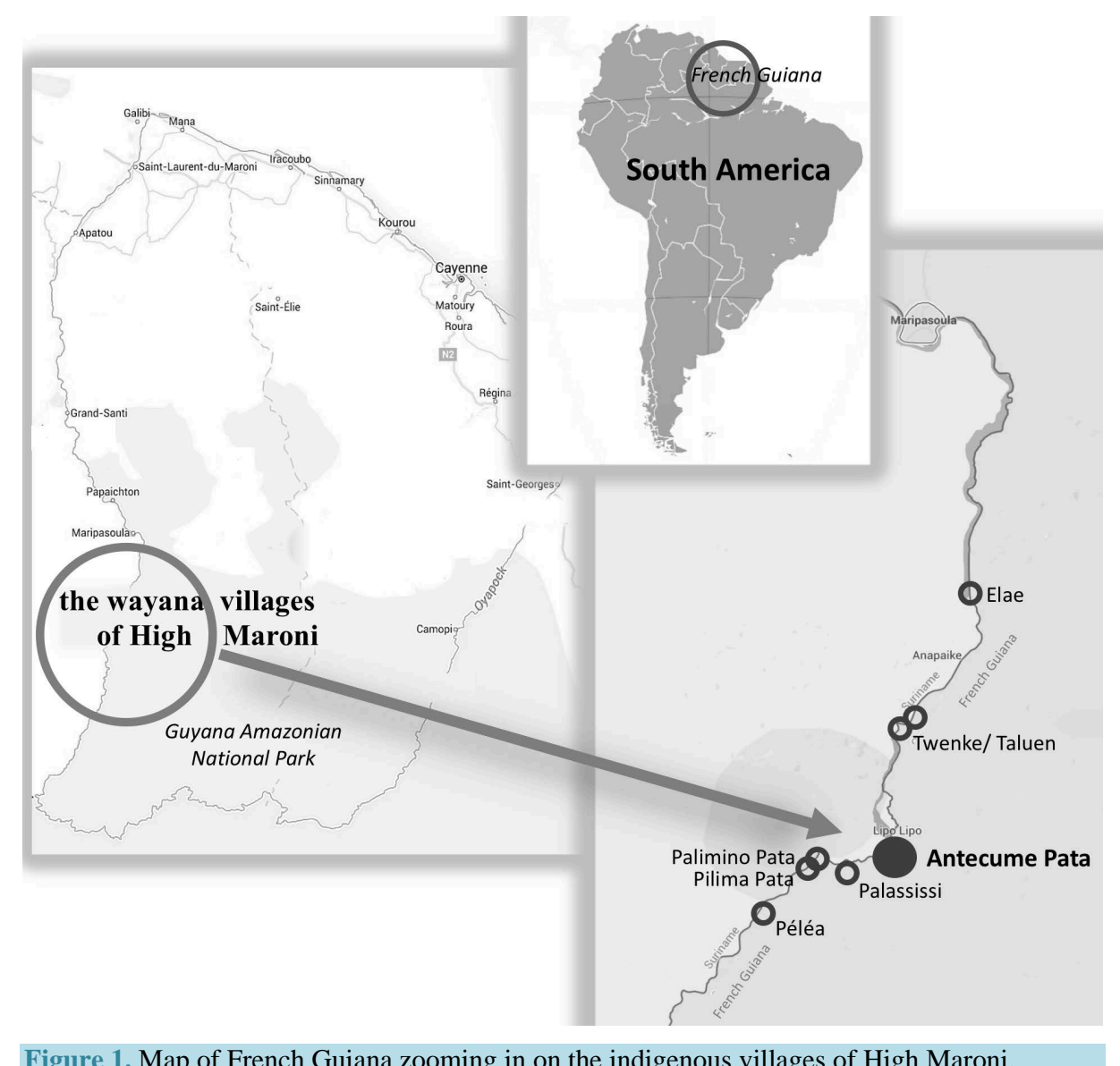

Figure 1. Map of French Guiana zooming in on the indigenous villages of High Maroni.

\footnotetext{
${ }^{2}$ The widespread definition of "indigenous country" is probably a colonial reference which brings to mind an image (perhaps nostalgic) of the "wild Amazon", of a "green hell” populated by Indians and "far from civilisation".
} 
Table 1. The Wayana population: inhabitants, pupils, classes.

\begin{tabular}{cccccc}
\hline & \multicolumn{5}{c}{ Wayana villages of HIGH Maroni $^{3}$} \\
Wayana villages & Antecume Pata $^{4}$ & Pilima Pata $^{5}$ & Cayodé & Elaé & Twenke-Taluwen \\
\hline Population & 300 inhabitants & 80 inhabitants & 150 inhabitants & 120 inhabitants & 500 inhabitants \\
Pupils, classes & 77 pupils & 2 classes & 45 pupils & 38 pupils & 110 pupils \\
& 4 classes & & 2 classes & 2 classes & 5 classes \\
\hline
\end{tabular}

However, schooling within these Wayana villages is quite recent ${ }^{6}$. The school represents the primary contact with the "outside" Western world (by the artefacts used, the knowledge it provides and by the academic standards it conveys through the presence of educational staff) ${ }^{7}$.

The school at Antecume pata ${ }^{8}$ was founded upon the initiative of André Cognat, who decided to create a school in his village in order to provide the Wayana of all ages with a basic schooling facility. One of his first objectives was the teaching of writing which was dependent upon local trainers. After this first phase, the school became a source of "dialogue" with modernity, offering French language courses. In 1986, the French Government officially recognised the Antecume pata teaching establishment by including it in the county's educational system. In our opinion, from an educational perspective, this event can be considered as the beginning of the status of "unwitting minority” for this community, as per Ogbu's definition.

André Cognat insisted strongly that the Wayana language ${ }^{9}$ have its place in school. As such, over a number of years, the introduction to writing was done in the Wayana language (firstly with the support of a cultural mediator and then with an ILM, a Mother Tongue Assistant, Intervenant en Langue Maternelle ${ }^{10}$ ), with pupils undergoing two years in the CP Preparatory Class, Classe Préparatoire, one in the Wayana language and the other in French. Upon request of the families, children could attend this school from five years of age.

Currently, all children of school age from these villages follow primary school education. It is with thanks to these children and their parents that we have been able to carry out this research study, the aims of which are, firstly, to describe the Wayana parenting system and, secondly, to understand its evolution within the context of dynamic interaction between the different systems (or microsystems).

\section{Analysis and Results}

Following the analysis of field observations and interviews with parents, we propose, firstly, a description of the social organisation of the Wayana (see sub-sections 4.1 and 4.2). In a second step, we then present the learning dynamics, educational roles and functions of parents, between tradition and modernity (see sub-sections 4.3 and 4.4).

\subsection{The Microsystem(s) of Wayana Kinship}

Kinship literally permeates the life of every Native American, from the moment he speaks and until the grave. This kinship allows each individual to position themselves to another, from where a network so tight is constructed that it alone constitutes the basis of ethnicity and interethnicity of the Wayana, the Wayampi and their neighbours (Hurault et al., 1998: p. 25: translated by the authors).

\footnotetext{
${ }^{3} 2012$ estimate.

${ }^{4}$ School attended by pupils from the following villages: Antecume Pata, Lipolipo and Palassissi.

${ }^{5}$ School attended by pupils from the following villages: Pilima Pata, Palimino Pata, Péléa.

${ }^{6}$ Antecume Pata (1986), Twenké (1972), Elahé (1985), Cayodé (1990).

${ }^{7}$ See also: Maurel, D. (2010). Indiens et Ecole en Guyane. Réflexion sur l’histoire de la scolarisation des Indigènes de Guyane française. In Maurel, D. (coord.). Vannerie et mathématiques en Guyane. (pp. 53-55). Guyane, Association Malipahpan.

${ }^{8}$ This Wayana village was founded in 1965 at the initiative of André Cognat, a worker from Lyon who became part of the indigenous community in 1961. For more information:

Cognat, A. (1977). Antecume ou Une autre vie. Paris: Robert Laffont. See also:

Cognat, A. (2009). [1967]. J'ai choisi d'être indien. Paris: L'Harmattan.

${ }^{9}$ Belonging to the Cariban language family. It is spoken not only by Wayana people (as L1) but also by Apalaï and Tiriyó (as L2).

${ }^{10}$ For more details, see also:

Maurel (2012). Genèse, fonctionnement et perspective du dispositif académique des Intervenants en Langue Maternelle (ILM) de la Guyane. In Ailincai, R. (Ed.). “L’informel dans l'éducation de l'enfant”. La revue française d'éducation comparée, 8, 223-242./voir également: Crouzier, M.F. (2007). Intervenants en langue et culture maternelles en Guyane : une efficacité à confirmer. Première évaluation d'un dispositif novateur sur le territoire français. 6e Congrès international d'Actualité de la Recherche en Education et en Formation, Strasbourg.
} 
The education and training of young Wayana builds up within both the family (one microsystem) and the village school (the other microsystem according to Bronfenbrenner's definition). The particularity of the indigenous Guiana people lies in their notion of family. For them, the family is "extended" and not limited to the nucleus (parents, brothers and sisters). For the traditionally endogamous ${ }^{11}$ Wayana kinship follows both patrilineal and matrilineal lines.

Kinships of both paternal and maternal origin position themselves and merge in such a way that the Wayana of High Maroni are all linked by some type of family relationship. The Wayana classification system has the same structure for both matrilineal and patrilineal relationships. For example:

- Women on the same line of rank $(n)$ consider themselves to be "sisters", whilst they consider women along the line $n-1$ as "mothers", along line $n-2$ as "grandmothers" and along line $n+1$ as "girls".

- Men who belong to the same uterine line consider all of the women belonging to the same line of rank $(n)$, as sisters and all women of line $n-1$, as mothers.

The diagram (a) in Figure 2 shows the nuclear family organised around biological parents, a microsystem similar to the classic Western model; diagram (b) meanwhile shows a microsystem specific to this sociocultural group (a microsystem based on another family in the village where the adult Wayana woman could be considered, according to these rules, as the mother of the child).

This organisation offers a specific structure of the family microsystem (see Figure 2(b)). This second model (b) concerns all the siblings of the child's biological parents and therefore offers many microsystems.

If we refer to Bronfenbrenner's model, the microsystems closest to the Wayana child correspond to all families in which the woman is considered to be the "mother".

All of these microsystems, not forgetting school, form the Wayana mesosystem (see Figure 3).

Regarding the family localisation system, we can say that the Wayana generally use a matrilocal pattern even though, in fact, the current demographic situation (growth of the indigenous population) has given a certain flexibility to traditional norms. Today, couples only set up home with the wife's parents if the latter can genuinely provide a sufficiently spacious and equipped home to host the married couple and future offspring.

Concerning the Wayana nomenclature, we present in Figure 4, the reference diagram from a female Ego which is symbolised by a triangle.

From the generation of the Ego, marked by an " $n$ " on the vertical axe, ensues the following:

- Downwards, the $n-1$ generation (the generation of the mother of the Ego) and $n-2$ generation (the generation of the grandmother of the Ego);

- And upwards, the $n+1$ generation (the children of the Ego).

For both girls and boys, preferred marriage is from the mother's brothers' side, that is, the children of the mother's brothers:

- As such, concerning the marriage of Wayana girls, the sons of maternal uncles are considered to be preferred spouses, whilst the sons of paternal aunts are considered as potential husbands (i-mnerum);

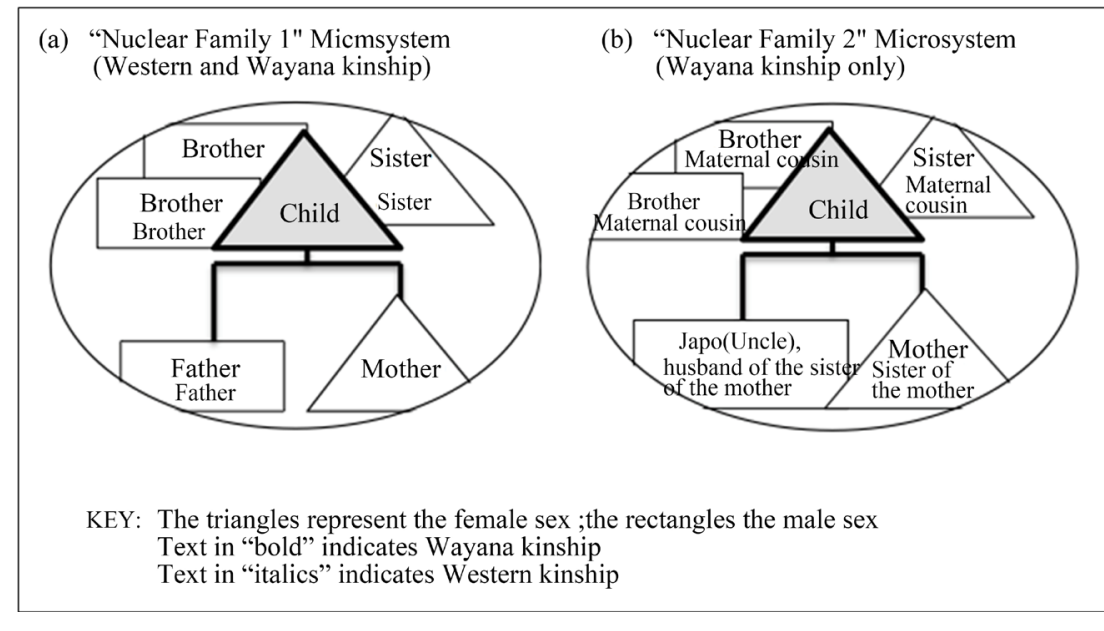

Figure 2. Two examples of the Wayana "family" microsystem (proposed by the authors).

\footnotetext{
${ }^{11}$ At the present time, the endogamous marriage is tending to disappear, for the benefit of exogamy.
} 


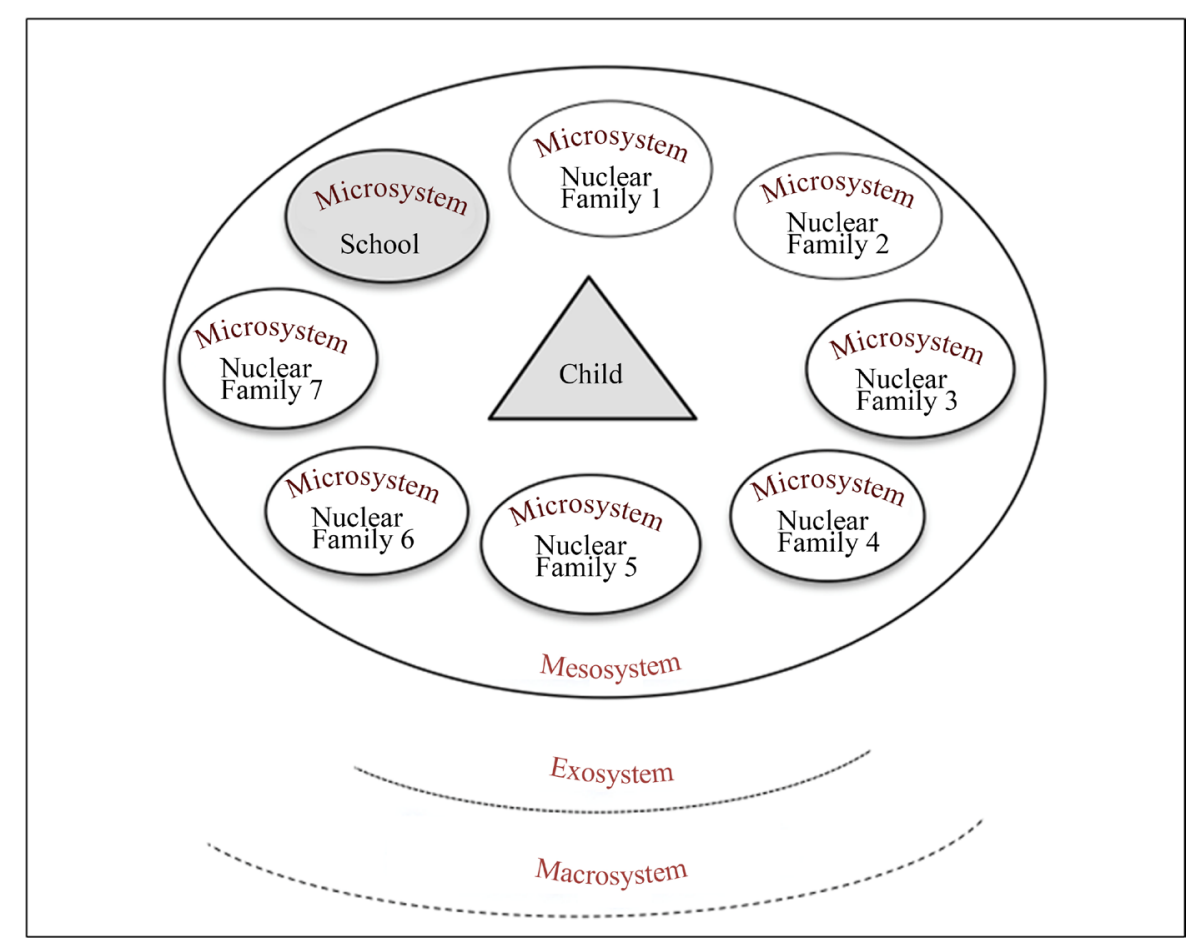

Figure 3. Structure of the Wayana mesosystem (diagram produced by the authors following Bronfenbrenner's ecological model, 1979).

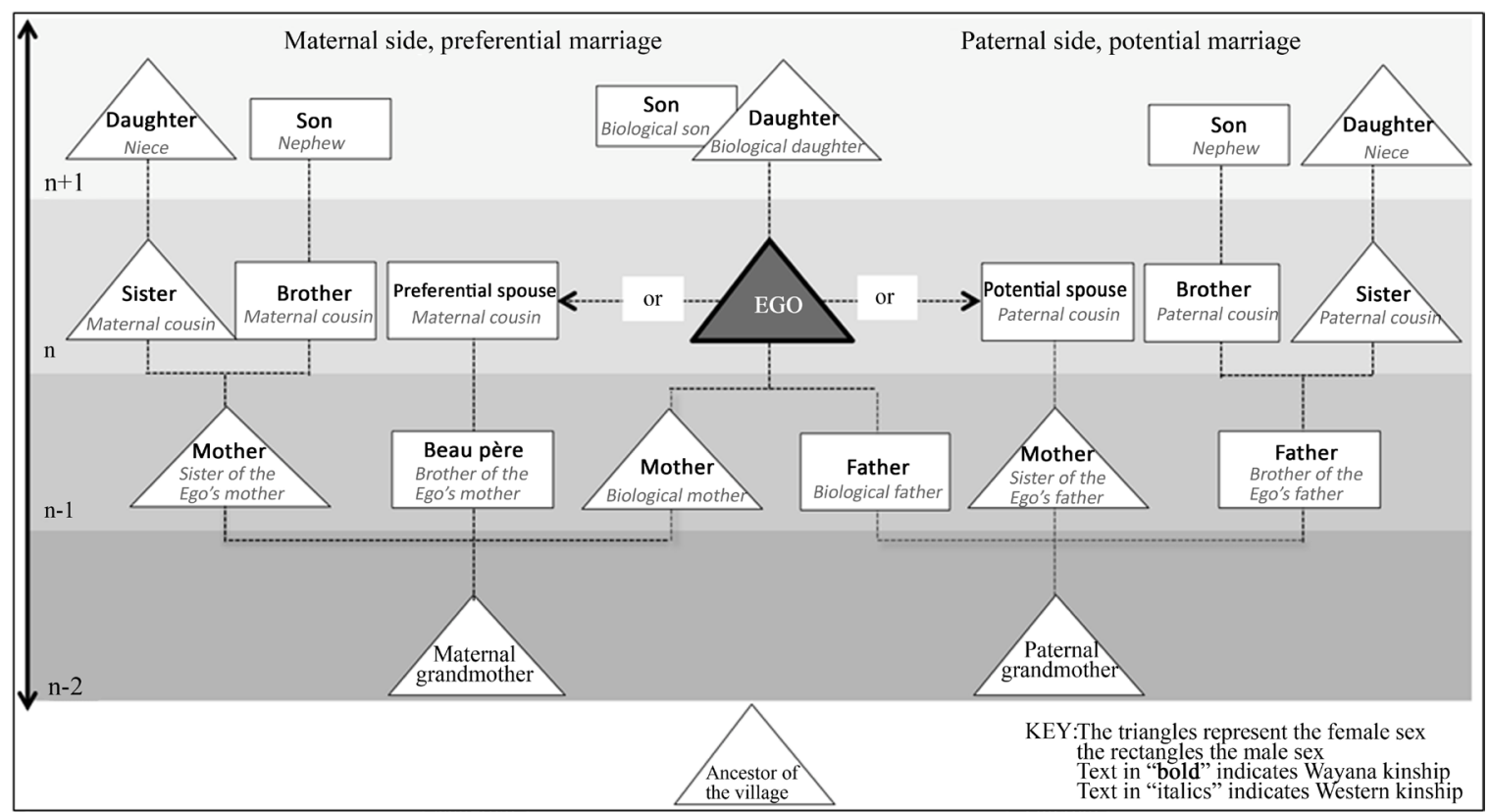

Figure 4. Diagram and Wayana reference nomenclature from the female Ego (on line n). Model produced by the authors. On the left part, we see the Wayana matrilineal diagram; whereas on the right side, we have the Wayana patrilineal diagram. To facilitate the reading, we used an ascendant graphic representation (at the bottom the ancestors and at the top the descendants).

- In the same way, for a Wayana boy, the daughters of maternal uncles are considered to be preferred spouses, whilst the daughters of paternal aunts are considered as potential wives (i-puit).

Usually, cross-cousins call themselves husband and wife even if they do not get married. Consequently, a hypothetical female Ego will call not only her own children i-mumu (my child), but also the children of her po- 
tential husbands (i-mnerum) and the children of her classified sisters ${ }^{12}$.

All in all, the fictitious filiation system derives from the fact that for a girl, all the men of her generation are considered to be either brothers or spouses.

These rules allow for a coherent classification system, maintaining the cohesion of the family system with precise definitions for genealogy, both horizontal (brothers, sisters, husbands, wives, brothers-in-law and sisters-in-law) and vertical (mothers, fathers, mothers-in-law, fathers-in-law for the " $n-1$ " generation; grandmothers, grandfathers for the " $n-2$ " generation; and daughters, sons, nephews and nieces for the " $n+1$ " generation.

\subsection{Nomos and Oikos: Community Organisation and Domestic Arrangements}

As with the majority of the peoples of nomadic tradition of the South American forests, an absence of the concept of private property between the Wayana as regards environmental and land resources can be noted, whereas, in the case of objects, the concept of family use is applied. Therefore, for a Wayana, it would be impossible to conceive a space (a plot of forest, a river, a hill) as personal wealth, yet it is normal for them to consider basketry as a tool belonging to the family (and to possibly lend it to other members of the community).

As Hurault states, "there is no form of appropriation of land to either individuals or the same groups of kinship, and it seems that there have never been any" (Hurault, 1972: p. 8: translated by the authors). This "ab-

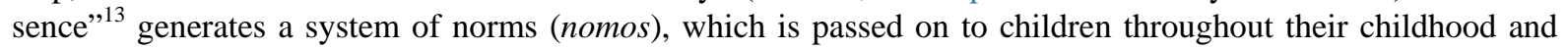
adolescence. This system aims to instruct both the young and adults to enable them to live in peace with other members of the community and prevent possible disputes (linked to the use of this type of resource), without recourse to the system of property deeds, which in reverse, forms the basis of the Western corpus iuris civilis.

It is therefore a certain "ecosophy" 14 which impregnates the Wayana culture, a "philosophy" of immanence strictly linked to its geographical and social panorama (oikos), which builds up in the family with the contribution of all community members (who, as we have seen, consider themselves to be, at any rate, members of the same family). It is an ongoing community instruction process and, from below, is directed at the respectful supply of natural resources and a sophisticated management of relationships with the community/family.

\subsection{Educational Roles and Functions of Parents, between Tradition and Modernity}

The ethnographic approach has allowed us to directly observe the way through which knowledge, skills and competencies are spread over time to become not only the knowledge of a new generation, but also (and probably above all) the achievements of an entire cultural community.

In brief, we can classify Wayana learning into three areas of knowledge which, obviously, are in relation to its reference ecosystem:

- Cultural knowledge (savoirs strictu sensu), which is embedded in its cosmology, shamanism, music and graphic art; it is also oral history and intangible heritage (stories, rituals, representations of the territory).

- Technical capacity, know-how (savoir-faire), which can be considered as the "real" response of the Wayana to the specific (and physical) characteristics of their environment. This is the "art" of hunting and fishing, cooking and production of cachiri (fermented manioc beer), but also of cotton weaving, basketry, the manufacturing of canoes and the construction of huts.

- Social skills (savoir vivre), which are represented by their Wayana' "ecosophical” "weltanshaaung” and their behaviour in the social and ecological context they occupy (e.g. the management of natural resources and the prevention and resolution of community disputes).

The training process with regard to children within the Wayana home provides very precise and specific roles and responsibilities for each member of the family.

\footnotetext{
${ }^{12}$ Actually, this is a typical "Iroquois" kinship system, based on the principle of bifurcate merging. It assigns the same term of classification of the father to paternal uncles and that of the mother to maternal aunts. Parallel cousins are then assimilated to siblings and the crossed cousins are considered "distant" relatives, which allow them to be potential husbands or wives.

${ }^{13}$ We use the term "absence" with a certain irony: modernity (and its neoliberal economic vision) has sometimes led us to consider societies which do not use a clear exchange system of goods and services based on a quotation, as "pre-modern" societies. Yet we must confess that: "The existential choices of the indigenous peoples, if they are by definition inadaptable to our economic requirements, our political models and our philosophical values represent however the only alternative that works in this tropical forest ecosystem" (Hurault et al., 1998: p. 26: translated by the authors).

${ }^{14}$ For a more in-depth description of the concept of ecosophy and a discussion on its implications in indigenous cultures, refer to Alì, 2010.
} 
Without going into details (which would be an ethnographic monograph alone), we present here a descriptive summary of our field observations. We would like to begin with the Wayana mother, who physically carries the child in her arms (with the help of a bandoulière ${ }^{15}$ shoulder strap) all day, from birth until two years of age. Many mothers continue to carry their children in the bandoulière until the child reaches three years of age, therefore a lot longer than the breastfeeding period ${ }^{16}$.

It is the mother who is responsible for the language education of the children, she will teach them how to speak and distinguish words related to everyday family life. Once the child reaches three years of age, the mother's role will be to teach her daughters: household chores and home life such as the tools and "timings" for cooking, settlement and spaces of the orchards (abattis), how to spin cotton and weave shoulder bags or hammocks and so forth; and, above all, the basic social skills such as having respect for the other members of the community and being readily available at any moment to properly host and welcome every possible guest of the family. The sons meanwhile will be trained in a series of skills that, as resumed by an Antecume Pata villager, consist of "knowing how to take care of themselves". Children will learn the "dangers" hidden in the house, the village and the orchard: the fire that burns, the caterpillar that bites, the river that drowns.

The educational role of the father is strictly linked to landscapes and spaces under the competence of the Wayana man: the river and the forest. He will train his daughters to "understand" the basic ideas behind the ecosystem in which they live so that when they grow up, they will be able to recognize the different noises and sounds of the forest, the different species of wild animals and how to prepare them for cooking. The father who brings back home a good choice of game represents a role model showing his daughters what a good hunter has to take back home to feed the family: a warning message too, so that the daughters can understand that the husbands they choose one day must be able to do the same thing (or better, if possible).

The boys will be trained in the art of living in a forest and a river environment, so that one day they become "a good father": hunting (with a bow and arrow for the younger ones and with a rifle for teenagers), fishing (and its different techniques: archery; poisoning of the river water (nivrée) ${ }^{17}$, lines and hooks; nets or "traps" in form of creels, for carnivorous predators such as the aïmara, weaving baskets with arouman fibres (Ischosiphon arouma), and making farming tools for tasks such as burning the orchard, building and steering of a pirogue (starting with a paddle for the small ones and, when older, with an outboard motor) and assembling a cabin. It is a slow and progressive learning process, a "training path" during which the child "carries out everything according to his rhythm: eating, sleeping, fishing with his short line. He has probably bothered an adult with his movements, his noises; or he has probably scared a fish away, yet no order will be proffered, no menace, and the child will not be reprimanded" (Hurault et al., 1998: p. 142: translated by the authors) ${ }^{18}$.

Grandparents are in charge of the child's instruction in the field of hygiene and health, using their knowledge of traditional remedies. They are also the key for passing on the oral heritage and Wayana oraliterature (Chapuis \& Rivière, 2003). As demonstrated by Suzy Platiel's ethno-linguistic works, such as tales are genuine educational institutions for societies based on oral tradition, as in the Wayana case (Platiel, 1993). Indeed, it is through this oral transmission of heritage that the grandparents contribute: to developing the child's listening, attention, hearing and memory skills, as well as the skills related to language (through the building up of vocabulary and the understanding of the syntax of the Wayana language); to determining logical relations (of cause and effect); to constructing hypotheses and arguments; and to solving everyday issues. One particular case is children being "offered" to grandparents, a tradition whereby parents can "give" one of their children to the grandparents (an already weaned child, although not the firstborn). In this case, the grandparents, who may come from the maternal or paternal lineage, will act as real parents for all purposes. For them, the only precondition to the "gift" is to have sufficient space, time and resources to nurture and instruct the "welcomed" child.

\footnotetext{
${ }^{15}$ The Wayana shoulder strap (bandoulière) is a miniature cotton hammock that women wear over the shoulder.

${ }^{16}$ Indeed, with the Wayana, "children are never alone [...]. Someone will try to understand the baby talk because all issues concerning children need an answer. Someone else will decrypt the future personality of the child by paying close attention to their behavior: those almost ethological (sic!) observations can determine the name the child will receive when they are able to walk without any aid [...]. Crying is considered as a serious threat for the child's development, so parents do all they can to avoid such a crisis: less talented women for this type of conciliation fall short on their reputation". (Hurault et al., 1998: p. 140: translated by the authors).

${ }^{17}$ Temporary poisoning of the river water with the juice of the rotenone like Lonchocarpus spp.

${ }^{18}$ We need to underline that this pattern of family training works only until adolescence. After that, teenagers will start a path of horizontal self-learning where the role of the parents diminishes in order to leave more space to other actors (friends, associates and same generation family members). For boys more than for girls, adolescence is the age of autonomy, "when they form gangs, when the oldest ones serve as a model more than the father himself, whose influence is now more discrete. It is the age of risk, the age when they start hunting in little groups and even alone, and when they get lost during one or two long days in the jungle” (Hurault et al. 1998: p. 144, translated by the authors).
} 
This tradition is not at all a removal of the child from his parents because, in most cases, the hut of the natural family is not far from that of the adoptive family ${ }^{19}$.

Other family members also have very specific responsibilities in relation to children. Elder siblings, for example, help take care of the youngest children of the same sex in their discovery of the world, as they represent the closest and easiest role model to follow (and they will be less demanding in case of failure). Aunts and uncles, who the parents see as potential wives and spouses, will be considered as step-parents for children who feel at home in their homes. Consequently, uncles and aunts treat their fictitious filiation exactly as they do to their natural children and with the same love, rigour and discipline.

Finally, other community members also interact with children's education, even if they are not "directly" linked with their family lineage ${ }^{20}$. Among all of them, shamans play very important roles, especially during the preparation of the marake ritual. The marake ritual, which is practised less and less in modern Wayana society, is part of essential knowledge in the Wayana culture. It is a celebration spread over several months, which brings tepiem (the initiated people) into a new stage of their life. The ceremony includes a series of strength and courage trials, chants (kalau) and traditional dances, finishing with the application on the body of the tepiem of a basket containing a large number of ants and wasps which sting the initiated and give them the strength to be reborn as real, authentic, Wayana people. The marake is not exactly a rite of passage as, traditionally, each Wayana had seven chances to pass the marake test before dying. It can however be considered as a "rebooting" ceremony to highlight either becoming an adult or, for those who are already adults, entering into a new stage of their existence.

Alongside his concrete functions (in medicine and social therapy, as well as Master of the Spirits, "the shaman, who is without doubt one of the most discreet, wisest and most cultivated of indigenous characters, remains the one upon whom we can count to resolve conflicts with nature, which frequently occur through human error-disregarding an interdiction for example, or between humans - unfulfilled revenge-or even conflicts between humans and forces beyond that, spirits and dead souls. Suffice to say that the happiness of the community and peace between communities often rests upon the action of the shaman" (Hurault et al., 1998: p. 27). For the Wayana child, a shaman is a reference point and an example of spiritual heroism.

According to the traditional outlook, the success of a young Wayana results from the internalization of the three domains of knowledge to which we referred earlier. For a boy, the main goal is to be a strong and courageous hunter; to become a man capable of building his home and responding to the natural household needs (hunting, fishing and maintenance of working tools); and above all to become a good father and husband. For a girl, the main goal is to be able to manage her house opportunely, to be able to brew a good quality cachiri for a community celebration and, obviously, to be a good wife and mother. To successfully perform in their lives, young Wayana have to grow up with a tough discipline of learning (also individually) which will help them acquire the skills needed to be a real Wayana, the moment of true success corresponding to the marake celebrations.

\subsection{Interactive Dynamics, between Tradition and Modernity}

Even if the educative model resulting from our fieldwork observations presented here seems to remain constant and loyal to the Wayana culture and heritage ${ }^{21}$, the parents' statements (and responses) during the interviews highlight a progressive dynamic related to their expectations focused, above all, on the children's success.

Description of the interviewed sample

Out of the 17 parents, 15 parents spoke French (more or less well), whereas only two parents did not speak any French. The interviews of these parents were carried out with the help of the ATSEM ${ }^{22}$.

\footnotetext{
${ }^{19}$ In this specific case, children continue to use the standard kinship terminology (e.g., fathers will be called "fathers", and grandfathers will be called "grandfathers"). Also, the relationship within the sibling doesn't change and the "offered" child is not supposed to acquire a "special” status.

${ }^{20}$ Here, we refer to the family in the sense of "lineage" since, as we have seen, in some way all members of a community have some sort of family bond.

${ }^{21}$ In this sense, our initial observations follow those observed before by other scholars in ethno-linguistic and anthropology studies (Hurault, Grenand, Grenand, Dupuy, 2007; Camargo, 2007; Léna, 2000); traditional educational practices in the transmission/acquisition of knowledge have been conserved; only the type of clothing seems to evolve (the traditional outfit-a little red loincloth called kalimbe or camisaworn by all pupils of the primary school in class is an increasingly rare sight outside of school. Indeed, it is no longer worn by the majority of high school students who come back to the community).

${ }^{22}$ Agent Territorial Spécialisé des Ecoles Maternelles—nursery school assistants who assist the teacher in the implementation of daily classroom activities. They depend on local government, not the Ministry of Education.
} 
Among 17 participants, 12 were women and five were men; 15 were 18 to 30 years old, two from 30 to 40 years old; and only four of them had jobs.

As the interviews were semi-open, six questions served as a common thread with the aim of gathering the parents' opinions about their children's success at school.

The following questions were asked during the interviews:

1) Why do you take your children to school?

2) Do you notice any differences between children who have gone to school and those who have never been to school?

3) What would you include into the school curricula? Why?

4) In which language would you like the teacher to talk to your child?

5) Do you think it would be a good opportunity to have a school for adults during the afternoon (e.g. two or three times every week?

6) If yes, would you participate (some of the time, if you have spare time)?

On the one hand, the results showed the importance given by parents to traditional learning and, on the other hand, the need to go to school, even if the reasons put forward differed ("to learn the language", "to have a paid job", "to learn something”, etc.). In all 17 interviews, parents underlined the importance of school, but only six parents agreed with the idea that their children should leave the village permanently (to go to school elsewhere). The other 11 parents preferred their children to grow up and live their life in the village. In general, the parents associated success with the traditional idea of "being a good Wayana" ("good fathers and mothers") or getting a wage-earning job "for the commune", as a public servant (police officer/teacher/nurse) or in areas of public interest (pirogue maker/carpenter). ${ }^{23}$

The responses obtained from the Wayana parents share similarities with the comments made by Ti'iwan Couchili ${ }^{24}$ (2010, p. 58): "Our elders knew how their children would be amputated of part of the knowledge they received. In exchange for this painful (but thought out) decision, which implies the abandonment of the seminomadic life, they hoped that a little part of us would be able to reach those public territorial jobs: nurse, teacher... We believe that willingness and open dialogue still characterizes today the totality of Guiana indigenous communities".

Other studies which were carried out between 2007 and 2011 confirm the importance of the school into the village's "landscape". In 2011, Garnier published the results of his 2010 survey with Wayana families about students attending boarding school (Internat d'excellence) away from home. When asked "Do you want your sons and daughters to continue their studies at college?”, 14 families out of 16 answered affirmatively, expressing the desire for their children to continue their studies and being integrated into Guianese, and even French, national society (some children go to school in Kourou, Cayenne and even in mainland France). Garnier's study highlights the parents' desire to see their children continue going to school, not only for compulsory studies, but also afterwards. This opinion is also confirmed by the experience of Ti'iwan Couchili: "Our generation is now in charge of evaluating the effects of the education system considering the expectations that led our parents to send us to school. These different school sites ${ }^{25}$ have not produced a bachelor. However, if we do not have a successful model, it is difficult to leave this behind this demeaning picture which has been shown to us for more than fifty years, since the opening (in Camopi) of the first primary school of the southern part of the country. French Guiana remains the last South American territory to have never promoted a local elite emanating from the regions considered as remote and which has always resisted intercultural education principles (Couchili, 2010: p. 58).

In his memoir, Garnier underlines the willingness of the Rectory to offer young Wayana, through the opening of the Maripasoula Internat d'excellence boarding school in 2010, an appropriate school framework contributing to the academic achievements of students in these villages (Garnier 2011).

The survey carried out by Gourg in 2005 (Gourg, 2010) showed the open-mindedness and pragmatism of the young Wayana towards the learning of foreign languages. 20 college students were interviewed; at the time, college lessons were provided in the village by coaches and teachers from the national education system, in conjunction with the National Centre for Distance Learning (Centre National d'Enseignement à Distance-

\footnotetext{
${ }^{23}$ Areas with a capitalist work logic which are certainly less "ecosophical” than the principle of a "good Wayana".

${ }^{24}$ Indigenous coordinator, FOAG Delegate, Deputy to the Mayor of Maripasoula, responsible for the villages south of the town.

${ }^{25}$ Camopi (1954), Trois sauts (1971), Twenké (1972), Elahé (1985), Antecume Pata (1986), Kayodé (1990), Pilima (1995), Yawapa (1997). Around 600 children are school here today.
} 
CNED). Interviewed students declared English as being the most useful language and Spanish the easiest, although they preferred learning Portuguese (Brazilian). These responses, taking into account the spatial distribution of the Wayana and their closest linguistic groups, are presented by Gourg as being realistic; moreover, Wayana parents stated their agreement with foreign language learning, with the survey revealing that a strong majority of parents had confidence in the teachers.

\section{Conclusion}

In this article, our concern to understand the formative dynamics of the Wayana is limited to the presentation of the social organisation of the group and the description of the educational facts observed. The interactionist theoretical framework and ecological models have enabled us to report on family educational practices and also, to show the dynamic generated by the interaction of the different systems.

The results of our observations present parenting practices in this indigenous community as being based on non-coercive performance, where nothing is forbidden, where learning is through observation and imitation without competition, without overvaluing/undervaluing, and where knowledge is transmitted orally and contextualised in a systemic approach. Children are instructed to create "relational niches" for what is "visible" and tangible, as well as myths and legends of the "world of spirits" for what is invisible (as per Ailincai et al., 2012). This style of education empowers children from an early age and defines them as having "extremely precocious maturity".

Not so long ago, success for younger Wayana people came down to the mastery of knowledge in relation to their reference ecosystem. Our research however has highlighted the emergence of new parental expectations, linked to the schooling of Wayana children and their access to the labour market.

The "changing" dynamic (evolving parental expectations regarding the success of the young Wayana) could be generated, according to Bronfenbrenner's meaning, by inter-system interaction, contacts and exchanges between the traditional and the modern. These are facilitated by the presence in the village of emblems of Western society, the school, village association, the schooling of young Wayana in the colleges and high schools of large towns and cities in Guiana, and the presence of people from "somewhere else" (the latter often being from national education, the neighbouring commune of Maripasoula, workers from the Amazonia National Park, etc.).

However, for the joint satisfaction of the two interacting microsystems, "family" (the Wayana education system) and "school" (the French school system), a mutual understanding of the concepts of "traditional success" and "academic success" ${ }^{26}$ seems essential to us.

The fact that the actors of the formal educational system use the term 'school failure' is the proof of lack of knowledge regarding the gap between these two types of concepts of success. We believe that instead of talking about the "school failure", we should work towards conceiving a school curriculum which could better answer the specific needs of these children.

Finally, we hope that our work will stimulate similar studies in the areas of the sociology of education, comparative education, and anthropology of childhood aiming to describe the peculiarity of these "peripheral"-and not very well-know-educative systems. We consider that it is fundamental to better understand the role played by local forms of knowledge transmission that enables indigenous communities to live in balance with their natural environment, to survive to the pressure imposed by several centuries of violent colonization and to adapt themselves to the cultural stress provoked by their integration to the national states and the "global village".

\section{References}

Ailincai, R., Jund, S., \& Ali, M. (2012). Comparaison des écosystèmes éducatifs chez deux groupes d'Amérindiens: Les Wayãpi et les Wayana. In Ailincai, R. (Ed.). “L’informel dans l'éducation de l'enfant”. La revue française d'éducation comparée, 8, 53-88.

Ali, M. (2010). En estado de sitio: Los kuna en Urabá. Vida cotidiana de una comunidad indígena en una zona de conflicto. Universidad de Los Andes, Facultad de Ciencias Sociales, Departamento de Antropología. Bogotá: Uniandes.

Berry, J. (1994). Ecology of Individualism and Collectivism. In U. Kim et al. (Eds.), Individualism and Collectivism: Theory, Method and Applications (pp. 77-84). Thousand Oaks: Sage.

Berry, J. W. (1971). Ecological and Cultural Factors in Spatial Perceptual Development. Canadian Journal of Behavioral

\footnotetext{
${ }^{26}$ Lahire (1993) suggests not to define, but rather to note, the historical and social variations of the notions of "success" and "failure" which are always a little vague: (Culture écrite et inégalités scolaires. Sociologie de l' “échec scolaire” à l'école primaire. PUL, Lyon, 1993).
} 
Science, 3, 324-336. http://dx.doi.org/10.1037/h0082275

Berry, J. W. (1976). Human Ecology and Cognitive Style. New York: Sage/Halsted/Wiley.

Berry, J. W. (1987). The Comparative Study of Cognitive Abilities. In S. H. Irvine, \& S. E. Newstead (Eds.), Intelligence and Cognition (pp. 393-420). Dordrecht: Martinus Nijhoff. http://dx.doi.org/10.1007/978-94-010-9437-5_10

Berry, J. W. (1995). The Descendants of a Model. Culture \& Psychology, 1, 373-380. http://dx.doi.org/10.1177/1354067X9513004

Blumer, H. (1969). Symbolic Interactionism: Perspective and Method. New Jersey: Prentice-Hall, Inc.

Bronfenbrenner, U. (1979). The Ecology of Human Development: Experiments by Nature and Design. Cambridge: Harvard University Press.

Bronfenbrenner, U. (1986). Ecology of the Family as a Context for Human Development: Research Perspectives. Developmental Psychology, 22, 723-742. http://dx.doi.org/10.1037/0012-1649.22.6.723

Bronfenbrenner, U. (1995). The Bioecological Model from a Life Course Perspective. In P. Moden, G. H. Elder, \& K. Luscher (Eds.), Examining Lives in Context (pp. 599-618). Washington DC: American Psychological Association. http://dx.doi.org/10.1037/10176-017

Bronfenbrenner, U. (2005). Making Human Beings Human: Bioecological Perspectives on Human Development. Thousand Oaks, CA: Sage.

Bronfenbrenner, U., \& Ceci, S. J. (1994). Nature-Nurture Reconceptualized in Developmental Perspectives: A Bioecological Model. Psychological Review, 101, 568-586. http://dx.doi.org/10.1037/0033-295X.101.4.568

Bronfenbrenner, U., \& Morris, P. (1998). The Ecology of Developmental Process. In W. Damon, \& R. M. Lerner (Eds.) Handbook of Child Psychology, Vol. 1. (pp. 993-1028). New York: John Wiley \& Sons, Inc.

Camargo, E. (2007). Lieu et langue. Paramètres d'identification et d'attribution du Soi et de l'Autre en wayana (caribe). In I. Léglise, \& B. Migge (Eds.), Pratiques et représentations linguistiques en Guyane (pp. 225-250). Paris: IRD Editions.

Chapuis, J., \& Rivière, H. (2003). Wayana eitoponpë. (Une) histoire (orale) des Indiens Wayana. Cayenne-Paris: Ibis Rouge.

Couchili, L. T. (2010). Un demi-siècle d'école dans le sud guyanais: quel bilan? In D. Maurel (Coord.). Vannerie et mathématiques en Guyane (pp. 56-58). Cayenne, Association Malipahpan.

Garfinkel, H. (1967). Studies in Ethnomethodology. Englewood Cliffs, NJ: Prentice-Hall.

Garnier, C. (2011). Le dispositif aide aux devoirs de l'internat d'excellence de Maripasoula: une voie vers l'intégration scolaire. L'exemple des élèves wayana du bâtiment des $6^{\text {ème }}$. Mémoire M2, (Dir. R. Ailincai), Antilles: Université des Antilles et de la Guyane.

Gourg, C. (2011). Hybridité et reliance: Représentations des langues vivantes étrangères en site isolé chez les jeunes Wayana d'Antecum Pata. In R. Ailincai, \& T. Mehinto (Eds.), Pratiques éducatives dans un contexte multiculturel. L'exemple plurilingue de la Guyane. (Vol. 2, pp. 97-104). CRDP Guyane.

Hurault, J.-M. (1968). Les Indiens Wayana de la Guyane française: structure sociale et coutume familiale. Paris: ORSTOM. Hurault, J.-M. (1972). Français et Indiens en Guyane, 1604-1972. Cayenne: Guyane Presse Diffusion.

Hurault, J.-M., Grenand, F., Grenand, P., \& Lévi-Strauss, C. (1998). Indiens de Guyane. Wayana et Wayampi de la forêt. Paris: Autrement, IRD.

Léna, S. (2000). Education amérindienne et éducation nationale. In Association Guyanaise des Psychologues, Deuxièmes journées d'études sur la famille en Guyane (pp. 78-91). Association Guyanaise des Psychologues.

Levine, R. A. (1967). Dreams and Deeds: Achievement Motivation in Nigeria. Chicago: University of Chicago Press.

Mead, M. (1928). Coming of Age in Samoa: A Psychological Study of Primitive Youth for Western Civilization. New York, William Morrow.

Mead, M. (1930). Growing Up in New Guinea: A Comparative Study of Primitive Education. New York: William Morrow.

Ogbu, J. U. (1985). Research Currents: Cultural-Ecological Influences on Minority School Learning. Language Arts, 62, 860-869.

Ogbu, J. U. (1990). Cultural Model, Identity, and Literacy. In J.W. Stigler, R.A. Shweder, \& G. Herdt (Eds.), Cultural Psychology: Essays on Comparative Human Development (pp. 520-541). New York: Cambridge University Press. http://dx.doi.org/10.1017/CBO9781139173728.020

Platiel, S. (1993). L'enfant face au conte. Cahiers de littérature orale: le temps de l'enfance, 33, 163-176. http://www.cerlom.fr/clo33.html

Super, C. M., \& Harkness, S. (1986). The Developmental Niche: A Conceptualization at the Interface of Child and Culture. International Journal of Behavioral Development, 9, 545-569. http://dx.doi.org/10.1177/016502548600900409 
Super, C. M., \& Harkness, S. (1997). The Cultural Structuring of Child Development. In J. W. Berry, P. R. Dasen, \& T. S. Saraswathi (Eds.), Handbook of Cross-Cultural Psychology, Vol. 2: Basic Processes and Human Development (2nd ed., pp. 1-40). Boston, MA: Allyn \& Bacon.

Valsiner, J. (1987). Culture and the Development of the Children's Action, a Cultural-Historical Theory of Developmental Psychology. New York: John Wiley \& Sons Inc.

\section{Submit or recommend next manuscript to SCIRP and we will provide best service for you:}

Accepting pre-submission inquiries through Email, Facebook, Linkedin, Twitter, etc A wide selection of journals (inclusive of 9 subjects, more than 200 journals)

Providing a 24-hour high-quality service

User-friendly online submission system

Fair and swift peer-review system

Efficient typesetting and proofreading procedure

Display of the result of downloads and visits, as well as the number of cited articles

Maximum dissemination of your research work

Submit your manuscript at: http://papersubmission.scirp.org/ 